\title{
Türkiye Hazır Giyim Sektörünün Sorunları, Çözüm Önerileri ve Rekabet Gücü (Problems of Turkey Clothing Industry, Solutions and Competitiveness)
}

\section{Muhittin ADIGÜZEL iD a}

a İstanbul Ticaret Üniversitesi İşletme Fakültesi İktisat Bölümü, İstanbul, Türkiye, madiguzel@ticaret.edu.tr

\begin{tabular}{|c|c|}
\hline MAKALE BİLGİSİ & ÖZET \\
\hline Anahtar Kelimeler: & Amaç: Türkiye hazır giyim sektörünün sorunları, çözüm önerileri ve rekabet gücünün belirlenmesi. \\
\hline $\begin{array}{l}\text { Türkiye Hazır Giyim Sektörü } \\
\text { Açıklanmış Karşılaştırmalı } \\
\text { Üstünlükler } \\
\text { Rekabet Gücü }\end{array}$ & $\begin{array}{l}\text { Tasarım/Yöntem/Yaklaşım: Hazır giyim ve konfeksiyon ile ilgili literatür ve ikincil kaynaklar } \\
\text { incelenmiş ve İstanbul Ticaret Odası ve İstanbul Ticaret Üniversitesi işbirliği bir çalıştay } \\
\text { gerçekleştirilerek sektör sorunları ve çözüm önerileri irdelenmiştir. Sektördeki firma yöneticileri ile } \\
\text { yüz yüze görüşmeler yapılmıştır. Türkiye hazır giyim ve konfeksiyon sektörünün uluslararası rekabet } \\
\text { gücü "Açıklanmış Karşılaştırmalı Üstünlükler” (AKÜ) yöntemi ile ölçülmüş ve sonuçları } \\
\text { değerlendirilmiştir. }\end{array}$ \\
\hline $\begin{array}{l}\text { Revizyon Tarihi } 28 \text { Kasım } 2019 \\
\text { Kabul Tarihi } 26 \text { Aralık } 2019\end{array}$ & $\begin{array}{l}\text { Bulgular: Sektörün başta gelen sorunları ortaya konulmuştur. Türkiye hazır giyim sektörünün 2005- } \\
2018 \text { yılları arasındaki rekabet gücünü ifade eden AKÜ indeks değerlerine bakıldığında hazır giyim } \\
\text { sektörünün genel çerçevede rekabet gücünün olduğu görülmektedir. }\end{array}$ \\
\hline $\begin{array}{l}\text { Makale Kategorisi: } \\
\text { Araştırma Makalesi }\end{array}$ & $\begin{array}{l}\text { Tartışma: Devlet ve sektörün birlikte; üretim maliyetlerini düşürecek, uluslararası rekabet gücünü } \\
\text { arttıracak vergi, SGK primleri, enerji maliyetleri, yatırım, teknoloji, ar-ge, üretim ve yeni pazarlar } \\
\text { oluşturulması ile ilgili politika ve uygulamaları geliştirmesine ihtiyaç duyulmaktadır. }\end{array}$ \\
\hline ARTICLE INFO & ABSTRACT \\
\hline Keywords: & Purpose: Turkey clothing sector problems, identifying solutions and competitiveness of \\
\hline $\begin{array}{l}\text { Turkey clothing sector } \\
\text { Revealed Comparative } \\
\text { Advantage }\end{array}$ & $\begin{array}{l}\text { Results: The major problems of the sector were revealed. With respect to } 2018 \text { Revealed Comparative } \\
\text { Advantage (RCA) index value of Turkey clothing sector between the years 2005-2018, that expresses } \\
\text { the power of competitiveness, it is seen that there is a power of competitiveness. }\end{array}$ \\
\hline $\begin{array}{l}\text { Received } 2 \text { September } 2019 \\
\text { Revised } 28 \text { November } 2019 \\
\text { Accepted } 26 \text { December } 2019\end{array}$ & $\begin{array}{l}\text { Design methodology/approach: Literature and secondary sources related to garment and apparel } \\
\text { sector were examined and sector problems and solution proposals were examined by a workshop in } \\
\text { collaboration with Istanbul Chamber of Commerce and Istanbul Commerce University. Face-to-face } \\
\text { interviews were conducted with company executives in the sector. The power of international } \\
\text { competitiveness of garment and apparel sector in Turkey was measured using the method "Revealed } \\
\text { Comparative Advantage" (RCA) and the results were evaluated. }\end{array}$ \\
\hline $\begin{array}{l}\text { Article Classification: } \\
\text { Research Article }\end{array}$ & $\begin{array}{l}\text { Discussion: State and sector together; It is necessary to develop policies and practices for reducing the } \\
\text { production costs and increasing the power of international competitiveness related with taxes, SSI } \\
\text { premiums, energy costs, investment, technology, R \& D, production and creation of new markets. }\end{array}$ \\
\hline
\end{tabular}

\section{GíRiş}

Türkiye tekstil ve hazır giyim sektörü, 1980 yılında başlatılan ihracata dönük politikalarla hızla büyümeye başlamış ve sektöre yapılan yatırımlar artmıştır. Tekstil ve hazır giyim sektörü birlikte değerlendirildiğinde, Gayri Safi Yurt İçi Hâsıla (GSYİH), imalat sanayi ve sanayi üretimindeki pay, ihracat, ekonomiye sağladığı net döviz girdisi, istihdam, yatırım gibi makro-ekonomik büyüklükler açısından Türkiye'nin önemli sektörlerinden birisidir (Özçalık ve Okur: 2013). Türkiye tekstil ve hazır giyim sektörü ihracat odaklı bir sektördür. Türk hazır giyim sektörü 2018 yılı itibariyle \%3,17 pay ile dünyanın 7'ıncı büyük hazır giyim ihracatçısı konumundadır (ITC Trademap). Ancak son yıllarda yakın coğrafyada yaşanan siyasi istikrarsızlıklar ve başta Avrupa olmak üzere diğer ihracat pazarlarındaki ekonomik sorunlar ve durgunluk, sektörde ciddi anlamda bir daralma meydana getirmiştir (İstanbul Hazır Giyim ve Konfeksiyon İhracatçıları Birliği [İHKİB],2014). 2014 yılında sektörün 18,7 Milyar Dolar olan ihracatı 2015 yılında \% 9,4 gerileyerek 16,9 milyar dolara düşmüştür. 2018 yılında ihracat 17,358 milyar dolar olmuştur. Hazır giyim sektörünün tanımlandığ 1 Gümrük Tarife İstatistik Pozisyonundaki 61. Fasıl 
“Örme Hazır Giyim”; 62. Fasıl “Dokuma Hazır Giyim”; 63.Fasıl “Dokumaya Elverişli Maddelerden Diğer Hazır Eşya" guruplarının 2001-2018 yılları arasındaki toplam dış ticaret fazlası yıllara göre Tablo 1'de yer almaktadır. Tekstil sektörü aşağıdaki tablonun içinde yer almamaktadır. Tablo 1 incelendiğinde 2001-2018 döneminde yalnız hazır giyim sektörü dış ticaret fazlasının toplam 226.665.645.000 Dolar olduğu görülmektedir (www.trademap.org; www.tuik.gov.tr). Bu rakamlar, sektörün Türkiye ekonomisi, ihracatı ve dış dengesi için önemini yeterince ortaya koymaktadır. Hazır giyim sektörünün tekstil sektörü ile bağlantısı da göz önüne alındığında iki sektörün Türkiye ekonomisinin stratejik sektörlerinden olduğu sonucu ortaya çıkmaktadır. Bu çalışmada, Türkiye ekonomisi açısından bu kadar önem taşıyan hazır giyim sektörünün sorunları ve çözüm önerileri öz bir şekilde ortaya konulmaya çalışılmıştır.

Bugün, hazır giyim sektörü, üretim ve istihdamdaki büyük ağırlı̆̆ıyla ülkemiz ekonomisinin lokomotif sektörlerinden birisi konumundadır. Sektörlerde faaliyet gösteren işletmelerin çoğu küçük ve orta büyüklükteki işletmeler niteliğindedir. Sosyal Güvenlik Kurumu 2017 yılı istatistiklerine göre, Türkiye genelinde giyim eşyaları imalatında faaliyet gösteren firmaların sayısı 33.071 olmuştur. Bu firmalarda kayıtlı yaklaşık 493.952 kişi istihdam edilmektedir (T.C. Ticaret Bakanlığı, 2019).

Tablo 1. Türkiye Hazır Giyim Sektörü Dış Ticaret Fazlası 2001-2014,(Bin Amerikan Doları)

\begin{tabular}{|l|l|l|l|l|l|l|l|}
\hline Y11 & Fazla & Y1l & Fazla & Y1l & Fazla & Y1l & Fazla \\
\hline $\mathbf{2 0 0 1}$ & 7.112 .859 & $\mathbf{2 0 0 2}$ & 8.645 .192 & $\mathbf{2 0 0 3}$ & 10.772 .273 & $\mathbf{2 0 0 4}$ & 12.030 .013 \\
\hline $\mathbf{2 0 0 5}$ & 12.671 .331 & $\mathbf{2 0 0 6}$ & 12.529 .717 & $\mathbf{2 0 0 7}$ & 14.057 .385 & $\mathbf{2 0 0 3}$ & 10.772 .273 \\
\hline $\mathbf{2 0 0 8}$ & 13.130 .004 & $\mathbf{2 0 0 9}$ & 10.849 .600 & $\mathbf{2 0 1 0}$ & 11.516 .312 & $\mathbf{2 0 1 1}$ & 12.485 .493 \\
\hline $\mathbf{2 0 1 2}$ & 13.267 .926 & $\mathbf{2 0 1 3}$ & 14.178 .873 & $\mathbf{2 0 0 3}$ & 10.772 .273 & $\mathbf{2 0 1 4}$ & 15.473 .186 \\
\hline $\mathbf{2 0 1 5}$ & 13.897 .692 & $\mathbf{2 0 1 6}$ & 14.037 .149 & $\mathbf{2 0 1 7}$ & 14.541 .109 & $\mathbf{2 0 1 8}$ & 15.505 .531 \\
\hline $\mathbf{2 0 0 1 - 2 0 1 8}$ Dönemi Diş Ticaret Fazlas1: 226.665.645.000 Dolar \\
\hline
\end{tabular}

Kaynak: ITC Trademap verilerinden hesaplanmıştır.

Hazır giyim sektörü sorunları ve çözüm önerilerinin belirlenmesi amacıyla; hazır giyim ile ilgili literatür ve ikincil kaynaklar incelenmiş ve sektör sorunları irdelenmiştir.

İstanbul Ticaret Odası (ITO) ve İstanbul Ticaret Üniversitesi işbirliği ile İTO Meslek Komitelerinde karşılaşılan başlıca sorunlar ve çözüm önerileri her ay yapılan bir anket ile derlenmekte olup araştırmada İTO Hazır Giyim ve Konfeksiyon Meslek Komitesi ile yapılan anket sonuçlarından bu çalışmada faydalanılmıştır.

Sektörün sorunlarının tespit edilmesi amacıyla sektör ile ilgili kamu ve sivil kurum, kuruluş ve firmaların temsilcileri ile İstanbul Ticaret Odası'nda sektör sorunları çalışma toplantısı düzenlenmiştir. Ayrıca çalışma toplantısı için İstanbul ilindeki sektör sivil toplum kuruluşlarından sektörün sorun ve çözüm önerileri ile ilgili görüşleri raporlar ile alınmıştır. Sektördeki firma yöneticileri ile yüz yüze görüşmeler yapılmıştır.

Gümrük Tarifesi İstatistik Pozisyonunda (GTIP) hazır giyim sektörünü tanımlayan fasıl 61, fasıl 62 ve fasıl 63 bazında Türkiye hazır giyim sektörünün uluslararası rekabet gücü "Açıklanmış Karşılaştırmalı Üstünlükler" (AKÜ) yöntemi ile ölçülmüş ve sonuçları değerlendirilmiştir. Yapılan bu faaliyetler bağlamında sektörün sorunları ve çözüm önerileri ile ilgili elde edilen veriler bu çalışmada ortaya konulmuştur.

\section{HAZIR GIYYIM VE KONFEKSIYYON SEKTÖRÜNÜN MAKRO DEĞERLENDİRMESİ}

\subsection{Dünya Hazır Giyim Sektörü}

Tekstil ve hazır giyim sektörü, ülkeler için daha ileri sanayilere geçiş için yarattığı sermaye birikimi ve nitelikli iş gücü nedeniyle önemli basamak taşlarından olarak görülmektedir (Aydoğdu, 2012:28). Dünya Ticaret Örgütü ve ekonomik küreselleşmenin etkisiyle Dünya hazır giyim sektöründe son yıllarda önemli değişim ve gelişmeler yaşanmıştır (Adıgüzel, M. (2011a). Dünya Ticaret Örgütü tarafından 1995 yılında imzalanan ve 2005 sonrası tekstil ve hazır giyim ticaretinin tamamen serbestleştirilmesini öngören "Tekstil ve Hazır Giyim Anlaşmasıyla" birlikte 2001 yılında Çin'in DTÖ’ye üyeliği dünya tekstil ve hazır giyim sektöründe Çin'in üretim merkezi olma dönemi başlamış, Bangladeş ve Vietnam gibi ülkeler gerek üretim maliyetlerinin düşük olması gerekse önemli ithalatçı ülkelerle imzalamış olduğu tercihli ticaret anlaşmaları ve düzenlemeleri sayesinde önemli üretici ve ihracatçı ülkeler konumuna erişmişlerdir. (Şahin, 2015; 158). 
2007 yılında Dünya hazır giyim sektörü harcamaları 1.328 milyar dolar iken 2015 yılında 1.713,6 milyar dolara ulaşmıştır. Üretim yönünden Asya bölgesinin ağırlığını arttırdığı, üretici ve ihracatçı ülkeler grubuna yeni ülkelerin katıldığı, bazı ülkelerin paylarını arttırdığı görülmektedir. Bu bağlamda Kamboçya, Bangladeş ve Sri Lanka'da hazır giyim sanayi ülke imalat sanayinin üçte birini oluşturması itibari ile hayati önem taşımaktadır. Bu üç ülkeyi Tunus izlemektedir. Beşinci sırada ise yüzde 6,9 payı ile Türkiye yer almaktadır. İzleyen ülkeler içinde Romanya, Portekiz, Pakistan ve Hindistan'da hazır giyim sanayinin payı artış göstermiştir (Türkiye Giyim Sanayicileri Derneği[TGSD],2016).

Dünya hazır giyim ihracatı 2018 yılında 547 milyar dolar ile dünya mal ihracatı içinde yüzde 2,82 pay almıştır. Çin 172,8 milyar dolar ile 31,57 paya sahiptir. İhracatçı ülkeler içinde başta Bangladeş, Vietnam ve Hindistan olmak üzere Asyalı ülkelerin payı artmıştır. Dünya hazır giyim ticaretinde gelişmiş ülkeler en büyük ithalatçıdırlar. Gelişmiş ekonomiler 2018 yılında sektördeki ithalatın 380 milyar dolarlık payına sahip iken Dünyanın diğer kısmı 167 milyar dolarlık paya sahiptir. İlk 20 en büyük ithalatçı ülke içinde 17 gelişmiş ülke bulunmaktadır. Çin de ilk yirmi ithalatçı arasına girmiştir. Avrupa Birliği 215 milyar dolar ile ilk ve ABD 131 milyar dolarla ikinci sırada yer almaktadır. Gelişen ülkeler içinden Rusya ve Polonya'nın ithalatı ve payları yükselmektedir (ITC Trademap, www.trademap.org).

Dünya tekstil ve hazır giyim dış ticaretindeki en önemli değişim Çin'in 11 Aralık 2001 tarihinde DTÖ'ye üyeliğiyle olmuştur. Çin bu üyelikle, DTÖ'nün “Tekstil ve Konfeksiyon Antlaşması "na tabii olmuş ve 2005 yılından itibaren kotaların kaldırılmasıyla tekstil ve hazır giyim ihracatını önemli oranda artırmıştır. Bununla birlikte, 1,3 milyarlık nüfusa sahip olan Çin aynı zamanda önemli bir pazar durumuna gelmiştir (T. C. Ticaret Bakanlığı, 2019).

Dünya hazır giyim sektöründe Çin en büyük üretici ve en büyük ihracatçı olup artan üretim maliyetleri nedeniyle üretimini üçüncü ülkelere kaydırmaktadır. Hindistan tekstil sektöründeki mukayeseli üstünlügü ile maliyet avantajı sağlamaktadır. Bangladeş, Pakistan ve Vietnam bu dönemin yeni önemli üç oyuncusu haline gelmiş olup Bangladeş ve Pakistan ucuz işgücü, pamuk-tekstil olanakları ve $A B$ ile yapılan ticaret anlaşmaları ile üretim ve ihracatlarını arttırmaktadır. Ucuz iş gücü ile Çin yatırımları için cazibe merkezi Vietnam, Sri Lanka, Kamboçya ve Filipinler olmuş ve bu çerçevede üretici-ihracatçı haline gelmektedirler. Mısır ve Fas, ABD ve AB ile sahip oldukları serbest ticaret anlaşmalarının avantajlarını ve bölgedeki göreceli ucuz işgücü maliyetlerini halen kullanmaktadır. Yeni bir üretim alanı olarak Afrika ülkelerinde işgücü ucuzdur ancak üretim ile ilgili kısıtlar mevcuttur. Çin yatırımları ile $\mathrm{AB}$ ve ABD ile yapılan serbest ticaret anlaşmaları gelecekte sektörde bir oyuncu olmasını sağlayabilecektir. Mısır ve Fas, $A B D$ ve $A B$ ile sahip oldukları serbest ticaret anlaşmalarının avantajlarını ve bölgedeki göreceli ucuz işgücü maliyetlerini halen kullanmaktadır. Romanya, İtalya ile Portekiz, İspanya ile entegrasyonunu geliştirmektedir. İtalya lüks segment liderliğini sürdürürken üretimde çalışan yabancıların katkısı artmaktadır. İtalya tedarik alanını da genişleterek üretici yanı sıra organizatör bir ihracatçı konumuna gelmektedir. Güney Amerika ve Orta Amerika ülkeleri ucuz işgücü, ABD ile yakınlıkları ve serbest ticaret anlaşmalarına rağmen Asya'nın rekabeti ile karşı karşıyadırlar (TGSD,2016; Fernandez-Stark,2015).

Tablo 2. Dünya'nın İlk 10 Giyim Eşyası İhracatçısı (2009),(Milyon Dolar) (GTIP 61,62,63)

\begin{tabular}{|l|c|c|}
\hline 2009 Dünya İhracatı & 358.697 .138 & Ülke İhracat Payı \% \\
\hline 1 Çin & 117.296 .063 & 32,7 \\
\hline 2 Hong Kong & 22.113 .377 & 6,16 \\
\hline 3 İtalya & 19.165 .971 & 5,34 \\
\hline 4 Almanya & 18.736 .378 & 5,22 \\
\hline 5 Hindistan & 13.630 .905 & 3,79 \\
\hline 6 Türkiye & 12.868 .196 & 3,58 \\
\hline 7 Bangladeş & 12.808 .891 & 3,57 \\
\hline 8 Fransa & 10.060 .667 & 2,80 \\
\hline 9 Vietnam & 8.865 .805 & 2,47 \\
\hline 10 İspanya & 7.820 .992 & 2,18 \\
\hline
\end{tabular}

Kaynak: ITC Trademap verilerinden oluşturulmuştur. 
Tablo 2 ve Tablo 3' de Dünya hazır giyim ihracatında 2009 ve 2018 yıllarındaki ilk on ihracatç ülke görülmektedir. Dünya hazır giyim ihracatı 2009 yılında 358 milyar dolar iken 2018 yılında 547 milyar dolara yükselmiştir. Bu rakamın 241 milyar doları örme ürünlerden, 239,5 milyar doları dokuma ürünlerinden 66,8 milyar doları da diğer ürünlerden oluşmaktadır. Bu dönemde Bangladeş payını yüzde 3,57' den yüzde 7,05'e Vietnam yüzde 2,47' den yüzde 5,88'e çıkarmıştır. Türkiye'nin payı yüzde 3,58' den yüzde 3,17'e gerilemiştir (ITC Trademap).

Tablo 3. Dünya'nın İlk 10 Giyim Eşyası İhracatçısı (2018),(Milyon Dolar) (GTIP 61, 62, 63)

\begin{tabular}{|l|l|c|}
\hline 2018 Dünya İhracatı & 547.298 .737 & Ülke İhracat Payı \% \\
\hline 1 Çin & 172.822 .517 & 31,57 \\
\hline 2 Bangladeş & 38.637 .279 & 7,05 \\
\hline 3 Vietnam & 32.202 .585 & 5,88 \\
\hline 4 Almanya & 26.538 .767 & 4,84 \\
\hline 5 İtalya & 24.069 .332 & 4,39 \\
\hline 6 Hindistan & 20.912 .195 & 3,82 \\
\hline 7 Türkiye & 17.358 .064 & 3,17 \\
\hline 8 İspanya & 15.973 .753 & 2,91 \\
\hline 9 Hong Kong & 13.404 .549 & 2,44 \\
\hline 10 Fransa & 12.919 .642 & 2,36 \\
\hline
\end{tabular}

Kaynak: ITC Trademap verilerinden oluşturulmuştur.

Dünya hazır giyim sektöründe, bir tarafta küresel markaları ile modern perakende pazarına hâkim olan, ancak üretimlerinin çoğunu ülke dışında yaptıran ülkeler yer alırken diğer tarafta çoğunu gelişen ülkelerin oluşturduğu hazır giyim sektörleri üretim ve ihracat ağırlıklı faaliyet gösteren ülkeler yer almaktadır. (Gereffi, G. and Memedovic, O. (2003); Gereffi, G. ve Frederick, S.2010). Günümüzde tekstil ve hazır giyimde Çin ve Asya'nın etkisi gün geçtikçe artmaktadır. (Yücel,2010); Allwood vd., 2015).

Dünya hazır giyim sektöründeki son yıllardaki değişim eğilimleri olarak; (TGSD,2016; T. C. Ticaret Bakanlığı, 2019; MÜSİAD,2014; T.C. Bilim, Sanayi ve Teknoloji Bakanlığı (2014), Hiller , (2010); Gill vd.(2016); Niinimäki ve Hassi, (2011); Armstrong vd. (2016))

- Son yıllarda hazır giyim sektöründe başta polyester olmak üzere suni ve sentetik elyaf ürünlerinin kullanım payı hızla artmaktadır.

- Dünya hazır giyim pazarında rekabet artmıştır.

- Dünya ekonomisindeki durgunluk ürün fiyatının önemini artırmıştır.

- Kotaların kalkmasıyla birlikte, büyük alım gruplarının alımlarını tek ya da birkaçülkede yoğunlaştırması ve bunu üreticiler üzerinde kullanması, fiyatlar konusunda üreticilerin aleyhine önemli bir baskı oluşturmuştur.

- Günümüzde ürün tedariki yanında hizmet sağlamakta önem kazanmıştır.

- Üretim/tedarik zinciri çok esnek olup alıcılar çok hızlı tedarikçi firma/ülke değiştirmeye devam etmektedir.

- UÜrün hayat süreleri kısalmış, kullanım sıklıkları azalmış ve ürün çeşitliliği/değişimi artmıştır.

- UUretici ve perakendecilerin kar marjları düşmüştür.

- E-ticaret yüksek büyüme hızına sahiptir.

- Markaların tasarımın ve modanın önemi artmıştır.

- Sipariş-Üretim-Teslim süreleri daha da kısalmıştır.

- Pazar farklılıklar içinde çok parçalı hale gelmiştir.

- Tekstil altyapısında sürekli yenilik ihtiyacı, elyaf, iplik, kumaşta artan inovasyon ihtiyacı olacaktır. Yeni malzemelerin kullanımı artacaktır.

- Ürünler ve ürün teknolojisinde önemli gelişmeler yaşanmakta olup üretimde yüksek teknoloji kullanımı artacaktır. İnovasyon, tasarım kadar önem kazanmaktadır. Tüketiciye erişimde ve tüm süreçlerde teknolojik altyapı ve dijital kanallar ve daha çok teknoloji kullanılacaktır.

- Gelişen ülkelerde yerel ve bölgesel markaların sayısı artacaktır.

- Tedarikte yakınlığın önemi artmakta olup yakın ülkelerden tedarik daha çok tercih edilecektir. 
- Bölgesel yeni nesil ticaret anlaşmaları ile tedarik zincirleri yeniden şekillenecektir.

- Pazarlarda eğilimler değişmektedir.

- Hızlı büyüyen gelişen ülke pazarlarının tercihleri ve alışkanlıkları üretim ve ürünleri daha çok şekillendirecektir.

- Artan kişiye özel talepler ile daha hızlı ve esnek küçük parti üretim öne çıkacaktır.

- Küresel moda başkentleri ana belirleyici olmaya devam ederken, moda merkezlerinde çeşitlenme ve bölgeselleşme yaşanacaktır.

\subsection{Türkiye Hazır Giyim Sektörü}

Tekstil ve hazır giyim sektörü, Türkiye ekonomisinin ulusal gelirini arttırıcı lokomotif sektörlerinden birisidir ve Türkiye'de istihdam ve ihracata sağlamış olduğu katkıdan dolayı, sosyo-ekonomik açıdan oldukça önemlidir (Özkaya, 2010: 144).Türkiye genelinde faaliyet gösteren yaklaşık 34000 firma ve kayıtlı yaklaşık 500000 kişi istihdamı ile imalat sanayi içerisinde istihdam bakımından birinci sırada yer alan Giyim Eşyalarının İmalatı sektörünün üretim değeri olarak imalat sanayi içindeki payı yüzde 6,23; katma değer payı ise yüzde 7,11 ile altıncı en büyük sektördür (Türkiye Kalkınma Bankası [TKB],2016).

Türk hazır giyim sanayi ihracatı 2008 yılında 13,59 milyar dolar iken 2009 yılında küresel kriz ile 12,686 milyar dolara gerilemiş, 2014 yılında 18,484 milyar dolara ulaşan ihracat, 2015 yılında yeniden 16,744 milyar dolara inmiştir. 2018 yılında 17,358 milyar dolara yükselmiştir. Hazır giyim sanayinin Türkiye'nin toplam ihracatı içindeki payı, 2009 yılında yüzde 12,59 iken 2012 yılında yüzde 10,37' a gerilemiş, 2018 yılında ise yüzde 10,33 oranında gerçekleşmiştir (ITC Trademap).

Sektörün sahip olduğu başlıca avantajlar; hızlı teslimat, hedef pazarlara olan yakınlık, teknik, sosyal ve idari bilgi birikimi, tecrübe, geniş ürün yelpazesi ve tasarım kapasitesi olarak sıralanabilir. Hazır giyim sektöründeki büyük firmalar son zamanlarda yurt içinde ve yurt dişında mağazalaşmaya yoğunlaşmışlardır. Türk hazır giyim sanayi esnek üretim yapısına sahip olup, değişen moda eğilimlerine de uyum sağlayarak yüksek katma değere sahip, modalı ürünler üretir konuma gelmiştir (T.C. Kalkınma Bakanlığı, 2014).

Türkiye 2018 yılında, Tablo 4'de yer aldığı gibi, 9 milyar dolarlık örme ürün (GTiP 61), 6,3 milyar dolarlık dokuma ürün (GTIP 62), 2 milyar dolarlık diğer ürünler (GTIP 63) ihracatı gerçekleştirmiştir. 2,8 milyar dolarla tişörtler, 1,9 milyar dolarla kazaklar, 1,24 milyar dolarla kadın ve kız çocuklar için takımlar ve 1 milyar dolarla çoraplar örme ürünler arasında en öne çıkan ihracat kalemleridir (ITC Trademap).

Tablo 4. Türkiye Hazır Giyim Sektörü Dış Ticareti,2009-2018,Bin Dolar

\begin{tabular}{|c|c|c|c|c|c|}
\hline & \multicolumn{2}{|l|}{ GTİP: 61, 62, 63 Toplam1 } & GTİP 61 & GTïP 62 & GTİP 63 \\
\hline Y1l & İhracat & İthalat & İhracat & İhracat & İhracat \\
\hline 2009 & 12.868 .196 & 2.020 .995 & 6.925 .548 & 4.294 .831 & 1.647 .817 \\
\hline 2010 & 14.205 .917 & 2.704 .271 & 7.731 .212 & 4.636 .123 & 1.838 .582 \\
\hline 2011 & 15.648 .661 & 3.165 .676 & 8.385 .636 & 5.124 .460 & 2.138 .565 \\
\hline 2012 & 15.753 .400 & 2.502 .473 & 8.418 .618 & 5.431 .268 & 1.903 .514 \\
\hline 2013 & 17.150 .270 & 2.971 .397 & 9.244 .940 & 5.714 .199 & 2.191 .131 \\
\hline 2014 & 18.484 .603 & 3.062 .450 & 10.024 .248 & 6.232 .503 & 2.227 .852 \\
\hline 2015 & 16.744 .623 & 2.846 .931 & 8.928 .097 & 5.917 .103 & 1.899 .423 \\
\hline 2016 & 16.728 .669 & 2.690 .818 & 8.849 .344 & 5.925 .410 & 1.953 .915 \\
\hline 2017 & 16.804 .601 & 2.263 .492 & 8.840 .031 & 5.947 .844 & 2.016 .726 \\
\hline 2018 & 17.358 .064 & 1.852 .595 & 9.043 .113 & 6.262 .454 & 2.052 .497 \\
\hline
\end{tabular}

Kaynak: Kaynak: ITC Trademap verilerinden oluşturulmuştur.

AB pazarındaki olumsuz gelişmelerin yanı sıra, son yıllarda komşu ve çevre ülkelerde yaşanan siyasi istikrarsızlık ile Dolar-Euro paritesindeki değişim tüm sektörlerde olduğu gibi hazır giyim ihracatımızı da olumsuz yönde etkilemiştir. 
M. Adigüzel 11/4 (2019) 3485-3504

Tablo 5.Türkiye'nin en fazla ihracat yaptığı 10 ülke,20014-2018, Bin Dolar

\begin{tabular}{|l|r|r|r|r|r|}
\hline Ülke & \multicolumn{1}{|c|}{$\mathbf{2 0 1 4}$} & \multicolumn{1}{|c|}{$\mathbf{2 0 1 5}$} & $\mathbf{2 0 1 6}$ & \multicolumn{1}{c|}{$\mathbf{2 0 1 7}$} & \multicolumn{1}{c|}{$\mathbf{2 0 1 8}$} \\
\hline Almanya & \multicolumn{1}{|c|}{3.871 .052} & 3.156 .956 & 3.138 .006 & 3.200 .075 & 3.164 .173 \\
\hline İspanya & 1.631 .684 & 1.666 .539 & 1.736 .474 & 2.080 .523 & 2.386 .711 \\
\hline İngiltere & 2.463 .363 & 2.187 .749 & 2.013 .293 & 1.943 .101 & 2.007 .256 \\
\hline Hollanda & 947.425 & 803.156 & 774.669 & 852.375 & 986.393 \\
\hline Fransa & 1.112 .960 & 871.429 & 836.313 & 833.193 & 875.295 \\
\hline ABD & 462.580 & 493.189 & 533.468 & 559.306 & 567.751 \\
\hline İtalya & 689.924 & 592.499 & 610.410 & 553.289 & 567.751 \\
\hline Danimarka & 502.021 & 401.149 & 422.257 & 389.992 & 407.753 \\
\hline İsrail & 225.859 & 250.856 & 300.017 & 321.389 & 352.195 \\
\hline Polonya & 434.410 & 445.627 & 555.893 & 426.397 & 348.402 \\
\hline
\end{tabular}

Kaynak: ITC Trademap verilerinden oluşturulmuştur.

Tablo 5'te Türkiye'nin en çok ihracat yaptığ 10 ülke yer almaktadır. Tablo 5'de görüldüğü gibi Almanya birinci, İngiltere ikinci, İspanya üçüncü sırada yer almaktadır.

Avrupa Birliği'nin hazır giyim ihracatımızdaki payı 2014 yılında 13,85 milyar dolar, 2018 yılı itibariyle 12,4 milyar dolar ile \%72'dir. 2018 yılı itibarıyla ihracat, Ortadoğu bölgesine yaklaşık 2 milyar dolar, Amerika kıtasına 724 milyon dolar, Afrika kıtasına 689 milyon dolar olmuştur. ABD'ne 595 milyon dolar, Rusya'ya 232 milyon dolar ihracatımız vardır (ITC Trademap). Hazır giyim alanında Türkiye'nin en önemli rakipleri, özellikle düşük ihraç fiyatlarına sahip Uzakdoğu ülkeleridir (Adıgüzel, M. 2011b).

2017 yılında hazır giyim ithalatımız 2,1 milyar dolar seviyesinde gerçekleşmiştir. 2018 yılında ise sektör ithalatı azalış göstererek 1,7 milyar dolar olarak gerçekleşmiştir. Çin, Bangladeş, Hindistan, Vietnam, Kamboçya, Sri Lanka, Endonezya ve Pakistan'dan gerçekleştirilen hazır giyim ithalatı 1998'de \%7 payla sadece 14,5 milyon dolarken, 2018 yılına gelindiğinde \%55,2 payla yaklaşık 934 milyon dolara ulaşmıştır. Diğer taraftan son yıllarda İtalya ve Mısır, ülkemiz ithalatında Uzakdoğu pazarlarını geride bırakarak öne çıkmıştır. Hazır giyim ithalatımızda Çin 1. sırada, Bangladeş 2. sırada, İtalya 3. Sırada ve Mısır 4. sırada yer almaktadır. 2017 yılında Çin'den \%29,2 azalış ile 510,5 milyon dolar; Bangladeş'ten \%35,7 azalış ile 419,3 milyon dolar; Mısır'dan ise \%10 artış ile 138,6 milyon dolar tutarında hazır giyim ithalatı yapılmıştır. Sektör ithalatında 3.sırada İtalya yer almaktadır. İtalya'dan 2018 yılında \%4,4 azalış ile 127,7 milyon dolar tutarında ithalat gerçekleştirilmiştir (ITC Trademap).

Tablo 6. Dünya ve Türkiye'nin Hazır Giyim Sektöründe İhracat ve Fasılların payı, 2009 ve 2018 yılları

\begin{tabular}{|c|c|c|c|c|}
\hline \multicolumn{5}{|c|}{ Dünya Hazır Giyim İhracatı (Bin Dolar) ve Fasılların Payı } \\
\hline & Toplam İhracat & GTİP 61 İhracatı & GTiP 62 İhracatı & GTIP 63 İhracatı \\
\hline 2009 & 358.697 .138 & $159.321 .545 \% 44,40$ & $156.761 .688 \% 43,7$ & $42.613 .905 \% 11,9$ \\
\hline 2018 & 547.298 .737 & $241.023 .039 \% 44,05$ & $239.495 .117 \% 43,75$ & $66.780 .581 \% 12,20$ \\
\hline \multicolumn{5}{|c|}{ Türkiye Hazır Giyim İhracatı (Bin Dolar) ve Fasılların Payı } \\
\hline & Toplam İhracat & GTIP 61 İhracatı & GTİP 62 İhracat1 & GTIP 63 İhracatı \\
\hline 2009 & 12.868 .196 & $6.925 .548 \% 53,82$ & $4.294 .831 \% 33,38$ & $1.647 .817 \% 12,80$ \\
\hline 2018 & 17.358 .064 & $9.043 .113 \% 52,09$ & 6.262 .454 & $2.052 .497 \% 11,83$ \\
\hline
\end{tabular}

Kaynak: ITC Trademap verilerinden oluşturulmuştur.

Tablo 6'da Dünya ve Türkiye'deki hazır giyim sektörünün ihracatının GTiP’na göre dağılımı yer almakta olup Türkiye'nin Örme grubu hazır giyimde ihracat payının Dünya ortalamasının üstünde, dokuma grubunda altında olduğu görülmektedir.

Tablo 7'de Türkiye' deki hazır giyim sektörü işyeri ve istihdamında en fazla sayıya sahip 10 ilimiz yer almaktadır. İşyeri sayısı olarak yüzde 68'i, istihdamının yüzde 51'i İstanbul ilindedir. İkinci sırada İzmir üçüncü sırada Bursa yer almaktadır. 
Tablo 7. Türkiye'nin hazır giyim sektöründe işyeri ve istihdamının en yüksek olduğu 10 İlimiz

\begin{tabular}{|c|c|c|}
\hline$\dot{\mathrm{I}} \mathrm{l}$ & İşyeri Sayısı & İstihdam Sayısı (kişi) \\
\hline 1. İstanbul & 22.494 & 252.536 \\
\hline 2. İzmir & 2.175 & 38.559 \\
\hline 3. Bursa & 1.617 & 16.633 \\
\hline 4. Batman & 126 & 9.457 \\
\hline 5. Denizli & 337 & 9.338 \\
\hline 6. Düzce & 90 & 7.848 \\
\hline 7. Mersin & 246 & 7.725 \\
\hline 8. Ankara & 725 & 7.382 \\
\hline 9. Adana & 415 & 7.188 \\
\hline 10. Tokat & 70 & 7.017 \\
\hline
\end{tabular}

Kaynak: http://www.sgk.gov.tr/wps/portal/sgk/tr/kurumsal/istatistik/sgk_istatistik_yilliklari

Tablo 8' de Türkiye' deki hazır giyim sektörü işyerlerinin istihdam açısından ortalama ölçekleri yer almaktadır. Tablo 8'de görüldüğü gibi sektör küçük ölçekli firma yoğunluklu yapısını sürdürmektedir. Sanayide 1-19 arasında kişi çalıştıran en küçük ölçekli firmalar girişim sayısının yüzde 86'sını oluşturmaktadırlar.

Tablo 8. Hazır Giyim ve Konfeksiyon Sektörü Firma İstihdam Büyüklükleri Dağılımı (Kişi,Firma Sayısı)

\begin{tabular}{|l|cccccccc|}
\hline Çalışan Sayısı & $\mathbf{1}$ & $\mathbf{2 - 3}$ & $\mathbf{4 - 6}$ & $\mathbf{7 - 9}$ & $\mathbf{1 0 - 1 9}$ & $\mathbf{2 0 - 2 9}$ & $\mathbf{3 0 - 4 9}$ & $\mathbf{5 0 - 9 9}$ \\
\hline Firma Adedi & 7.390 & 8.601 & 6.054 & 2.824 & 3.465 & 1.446 & 1.354 & 1.031 \\
\hline Çalışan Sayısı & $\mathbf{1 0 0 - 2 4 9}$ & $\mathbf{2 5 0 - 4 9 9}$ & $\mathbf{5 0 0 - 7 4 9}$ & $\mathbf{7 5 0 - 9 9 9}$ & $\mathbf{1 0 0 0}$ ve üzeri & & \\
\hline Firma Adedi & 692 & 159 & 28 & 12 & 15 & & & \\
\hline
\end{tabular}

Kaynak: http://www.sgk.gov.tr/wps/portal/sgk/tr/kurumsal/istatistik/sgk_istatistik_yilliklari

Çalışan sayısı 20 ve üzeri şirketler bağlamındaki bir araştırma sonuçlarına göre hazır giyim sektörü, ARGE harcamaları satışların yüzde 0,03'ü olarak Türkiye'de en düşük orandaki ARGE harcaması yapan ikinci sektördür. Yine sektörde Bilgi Temelli Yatırımların satışlara oranı yüzde 0,46 ile imalat sanayi içinde en düşük sektördür. Bu rakamların çalışan sayısı 20'nin altındaki şirketlerde çok daha düşük seviyelerde olduğu değerlendirilmektedir. Hazır giyim karlılık endeksinde karlılık seviyesi 2007 yılı için 100 kabul edildiğinde 2015 yılı sonunda 83,82 puan seviyesine gerilemiştir. İthal kumaş maliyetleri endeksi aynı dönemde yüzde 156,74 yükselmiştir. Hazır giyim sanayinde 2007-2015 döneminde yüksek katma değerli üretim, daha yüksek fiyatlı ürün ihracatı ve üretimde verimlilik artışına rağmen maliyetlerde oluşan kontrol dışı artışlar karlılığın gerilemesine yol açmıştır. Türkiye 2017/18 sezonunda dünyanın 7'inci büyük pamuk üreticisi olmasına karşın, yerli üretim iç talebi karşılamamaktadır. Ülkemiz dünya pamuk tüketiminde 6'ıncı sırada almaktadır. Hazır giyim sektöründe Özkaynaklar/Toplam Aktifler Oranında düşüş görülmektedir. 2008 yılında yüzde 39.7 olan bu oran 2014 yılında yüzde 32' lere gerilemiştir. 2018' de ülkemizde yaşanan döviz kuru şoku bu durumu daha da kötüleştirdiği ve finansman maliyetlerini büyük oranda yükselttiği değerlendirilmektedir.

\section{HAZIR GIYIMM VE KONFEKSIYYON SEKTÖRÜ SORUNLARI VE ÇÖZÜM ÖNERILERİ}

\section{1. İTO Hazır Giyim ve Konfeksiyon Komitesinde Bildirilen Sorunlar}

İstanbul Ticaret Odası ve İstanbul Ticaret Üniversitesi işbirliği İTO Hazır Giyim ve Konfeksiyon Komitesi'nde karşılaşılan başlıca sorunlar ve çözüm önerilerinin belirlenmesi amacıyla her ay yapılan bir anketin sonuçları aşağıda Grafik 1, Grafik 2 ve Tablo 9'da verilmiştir. 


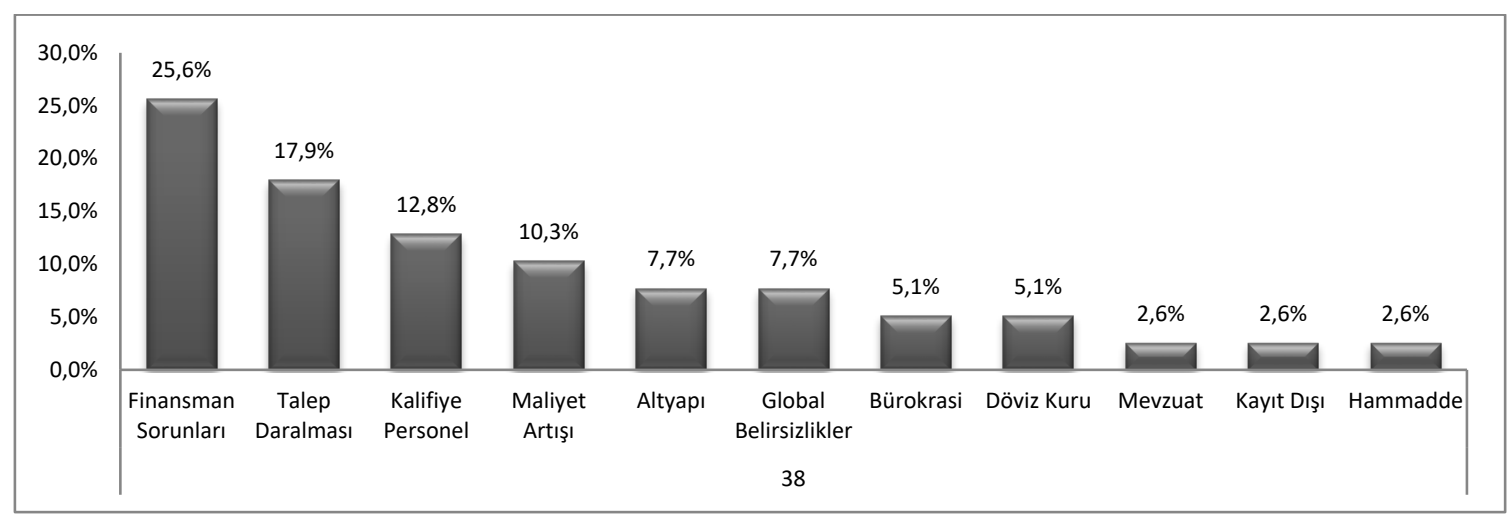

Grafik 1. Hazır Giyim ve Konfeksiyon Komitesinde Bildirilen Sorunların Dağılımı

Kaynak: Elçin Aykaç Alp, Mete Han Yağmur, 2017

Tablo 9. Hazır Giyim ve Konfeksiyon Komitesinde Karşılaşılan Başlıca Sorunlar ve Çözüm Önerileri

\begin{tabular}{|c|c|}
\hline Sorun & Çözüm önerisi \\
\hline Finansman sorunları & Bankalardan daha uygun kredi sağlanması, faiz dışı masrafların düşürülmesi \\
\hline Talep daralması & $\begin{array}{l}\text { Tanıtım ve pazarlama faaliyetlerinin desteklenmesi ve arttırılması, sektörlere yönelik } \\
\text { yeni pazarlar bulunması için çalışmalar yapılması }\end{array}$ \\
\hline $\begin{array}{l}\text { Kalifiye personel } \\
\text { eksikliği }\end{array}$ & $\begin{array}{l}\text { Meslek lisesi, ön lisans, lisans öğretimi ve sertifika eğitimleri, mesleki kurslar konusund } \\
\text { inisiyatif kullanılması }\end{array}$ \\
\hline Maliyet artışı & Fiyat ve vergi politikasında iyileştirme yapılması \\
\hline Altyapı eksikliği & $\begin{array}{l}\text { Çevre ve trafikte yaşanan sorunların giderilmesine ilişkin projeler hazırlanması ve } \\
\text { mevzuatta düzenlemeler yapılması }\end{array}$ \\
\hline Global belirsizlikler & Komşu ülkelerde yaşanan daralma ve istikrarsızlıktan kaynaklanan sorunlar \\
\hline Bürokrasi & Mevzuatın basitleştirilmesi ve hızlı uygulanır hale getirilmesi \\
\hline Döviz kuru & Döviz kurunda aşırı dalgalanmaların ve belirsizliğinin giderilmesi \\
\hline $\begin{array}{l}\text { Mevzuattan } \\
\text { kaynaklanan üretim } \\
\text { sürecini aksatan } \\
\text { sorunlar }\end{array}$ & $\begin{array}{l}\text { Mevzuatın takip edilmesi ve bilgilendirilmesi, yapılacak düzenlemeler ve uygulamadal } \\
\text { aksaklıklar konusunda komitelerin görüşlerinin kamu otoritesine aktarılması, mevzuat } \\
\text { değişikliğinde komitelerden gelen önerilerin dikkate alınması. }\end{array}$ \\
\hline Kayıt dışı & Denetimlerin arttırılması, yaptırımlar uygulanması, vergi yüklerinin düzenlenmesi \\
\hline Hammadde & $\begin{array}{l}\text { Hammadde temin sürecinde yaşanan aksaklıkların çözümü için kamu otoritesinin ilgili } \\
\text { sektörlerde planlama ve teşviklerde bulunması }\end{array}$ \\
\hline
\end{tabular}

Kaynak: Elçin Aykaç Alp, Mete Han Yağmur,2017

Hazır giyim ve konfeksiyon komitesi tarafından bildirilen finansman sorunlarının temelinde banka faizlerinin yüksekliği ve faizsiz kredi desteği bulunamaması tespitleri yer almaktadır. Ayrıca iç piyasada, ihracat yapılan ülke ekonomilerinde daralma sebebiyle finansman ihtiyacının çoğalması vurgulanmıştır.

Talep daralması sorununa ilişkin tespitlerde iç ve diş piyasada ekonomik daralma sebebiyle oluşan durumun yeni pazarların bulunarak aşılabileceği bunun için sektöre ilişkin tanıtım ve pazarlama faaliyetlerinin desteklenmesi önerilmiştir.

Sektörün ara eleman ihtiyacının karşılanması için sektöre ilişkin bilgilendirmenin yapılması uygun eğitim birimlerinin açılması önerilmiştir.

Sektörde görülen temel maliyet kalemi üretim maliyetleri olarak tespit edilmiştir. Çözüme yönelik ise fiyat ve vergi politikasında iyileştirme özellikle de istihdama ilişkin maliyetlerde iyileştirme talep edilmektedir.

İlk 4 sorun ise "finansman sorunları", "talep daralması", "maliyet artışı" ve "kalifiye personel" 'dir. 


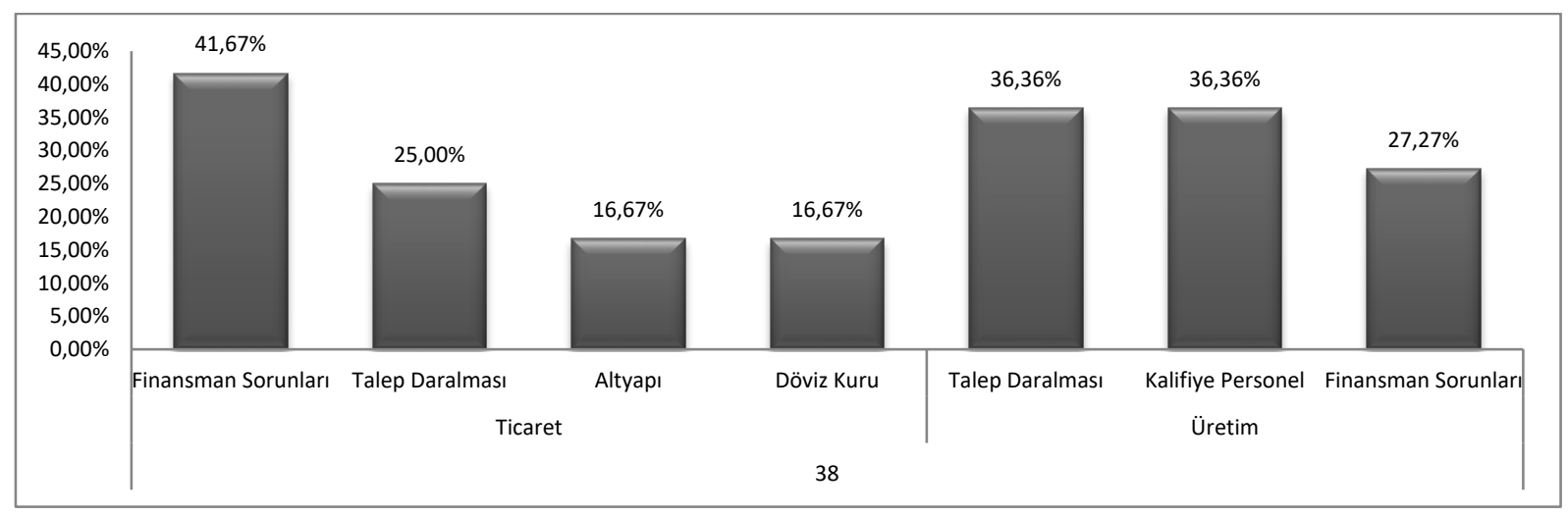

Grafik 2.Hazır Giyim ve Konfeksiyon Komitesinde Faaliyet Alanına Göre Bildirilen Başlıca Sorunlar

Kaynak: Elçin Aykaç Alp, Mete Han Yağmur, 2017

Sektörde ticaret ve üretim alanında faaliyet gösteren firmaların yaşadığı sorunlarda da önem sırasına göre farklılaşma mevcuttur. Sektörde ticaret alanında faaliyet gösteren firmaların başlıca sorunları; "finansman sorunu", "talep daralması", "alt yapı sorunları" ve "döviz kurunda" yaşanan dalgalanmaya ilişkin sorunlardır.

Üretim alanında faaliyet gösteren işletmelerde ise temel sorunun "talep daralması" ikinci sırada "kalifiye personel" sorunudur. Üretim alanında faaliyet gösteren firmalarda finansman sorunu üçüncü sırada gelmektedir.

\subsection{Hazır Giyim Sektörünce Belirlenen Sorunlar}

Araştırma kapsamında İstanbul Ticaret Odası'nda sektör ile ilgili kamu ve sivil kurum ve kuruluşların temsilcilerinden oluşan yaklaşık 250 katılımcı ile İstanbul Ticaret Odası'nda sektör sorunları çalışma toplantısı düzenlenmiştir. Sektörün aşağıda verilen sorunları büyük ölçüde bu çalıştayda tespit edilmiştir. Ayrıca çalışma toplantısı için İstanbul ilindeki sektör sivil toplum kuruluşlarından sektörün sorun ve çözüm önerileri ile ilgili görüşleri alınmıştır. ${ }^{1}$ Sektördeki firma yöneticileri ile yüz yüze görüşmeler yapılmıştır. Belirlenen sorunlar ve çözüm önerileri aşağıdaki başlıklar altında toplanmıştır;

1. Tasarım, ürün geliştirme

2. Hammadde ve yarı mamul

3. Üretim
a. Personel ve işçilik
b. Enerji
c. Makina-teknoloji

4. Pazarlama ve satış

5. Finansman

6. Piyasa ve sektör koşulları

7. Mevzuat

8. İhracat

9. İthalat

10. Çalışma mevzuatı

11. Teşvik sistemi ve yatırım

12. Fuarlar

13. Vergiler

14. Diğer konular

Bu kapsamda belirlenen sorunlar ve çözüm önerileri aşağıda verilmiştir.

\footnotetext{
1'̇stanbul Ticaret Odası,2015. 16 Aralık 2015 tarihli Hazır Giyim ve Konfeksiyon Sektörü Sorunları Çalışma Toplantısı Tutanakları, Bayrampaşa Tekstilci ve Sanayici İş Adamları Derneği,2015. “Hazır Giyim Sektörü” Yayınlanmamış Raporu,

Laleli Sanayici ve İşadamları Derneği,2015. Rusya Federasyonu İle Yaşadığımız Ticari Sorunlara İlişkin Çözüm Önerileri Raporu,

Merter Sanayici ve İşadamları Derneği, 2015. "Hazır Giyim Sektörü Sorunları” Yayınlanmamış Raporu, İstanbul

Osmanbey Tekstilci İş Adamları Derneği,2015. “Hazır Giyim Sektörünün Sorunları” Yayınlanmamış Rapor
} 


\section{Tasarım, Ürün Geliştirme}

\section{A. Sorunlar}

1) Turquality ve marka destek programı kapsamındaki uygulamaların bürokratik engeller ile zorluklar taşıması ve gecikmeli olması

2) Şirketlerin kendi bünyelerinde gerçekleştirdikleri tasarım faaliyetlerinin desteklenmesi (Turquality ve marka destek programı hariç),uygulamasının etkin olarak gerçekleşmemesi

3) Markalaşma eğiliminin sınırlı kalması

4) Yüksek katma değerli ürün tasarımında ve üretiminde istenilen seviyeye gelinememesi

\section{B. Çözüm Önerileri}

1) Tasarım ve ürün geliştirme projeleri desteğine ilişkin uygulama usul ve esasları genelgesinin hazırlanmasında sektör temsilcilerinin görüşlerinin alınması, tasarım desteklerinin mevcut tasarım kapasitesini kurmuş olup geliştirecek olan firmalar için nasıl uygulanacağının detaylandırılması, tasarımcı ve sanayi işbirliğinin arttırılmasına dönük tedbirlerin alınması

2) Dünya moda merkezlerindeki kurumlar ile işbirliği kurulması, ortak etkinlikler gerçekleştirilmesi

3) İstanbul moda akademisi ve benzeri kurumların eğitim katkısının arttırılması

\section{Hammadde ve Yarı mamul}

\section{A. Sorunlar}

1) Türk hazır giyim sektörünün son yıllarda pamukta ithalata bağımlı hale gelmesi.

2) Hammadde, aksesuar ve ithal kumaşlara getirilen korunma önlemleri ile artan girdi maliyetlerinin rekabet gücünü azaltması. Polyester kumaşta gerekli yatıımların yapılmamış olmasının, rekabet gücümüzü olumsuz etkilemesi.

\section{B. Çözüm Önerileri}

1) Giyim eşyaları sanayi için ana hammaddeler, pamuk, polyester iplik/kumaş, ham deri ve kürk ve kıymetli kürk postları olup bu hammaddelerin yurtiçi üretiminin desteklenmesi,

2) Yurtiçi iplik ve kumaş üretiminin desteklenmesi

\section{3.Üretim}

\section{A. Sorunlar}

\section{Personel ve İşçilik}

1) Sektör olarak en büyük sıkıntılarımızdan birisi kalifiye/vasıfsız eleman açı̆̆ıdır. Mesleki eğitim, sanayinin artan ve çeşitlenen insan kaynakları ihtiyaçlarını yeterince karşılayamamaktadır.

2) Türkiye hazır giyim sektöründe başta işgücü olmak üzere üretim maliyetleri rakip ülkeler ile karşılaştırıldığında yüksek kalmaktadır. Bangladeş'te iş̧̧ilik ücreti 0.65 cent, Vietnam'da 0.74 cent, Hindistan'da 1.12 dolar, Çin' de 2.65 dolar iken bizde 5.5 dolardır.

3) Sektör yeni nesil nitelikli insan kaynağı bulmakta ve yetenekli eğitimli işgücü çekmekte sıkıntı yaşamaktadır.

4) Sektörde kayıt dışı istihdam sorunu vardır.

5) Yurt dışı mağazacılıkta, pazarlamada, moda yönetiminde, nitelikli eleman ihtiyacı vardır.

\section{Enerji}

1) Pahalı enerji, Türk tekstil ve konfeksiyon sektörünü dünya pazarlarındaki rekabet gücünü olumsuz yönde etkilemektedir.

\section{Makina-Teknoloji}

1) Tekstil üretim makine ve yedek parçalarında yurtdışına bağımlılık vardır.

2) KOBI'ler yenilikleri takip edememekte ve araştırma ve geliştirme (ar-ge) faaliyetlerinden uzak kalmaktadır.

\section{Üretim Tesisi}

1) İstanbul'da arsa ve yerleşim sorunu vardır. 


\section{B. Çözüm Önerileri}

1) Üretimin pozitif ayırımcılıkla desteklenmesi, üretim ve sanayi üzerindeki yüklerin hafifletilmesi ve ihracata odaklı büyüme politikasının devam ettirilmesi

2) Yüksek katma değerli üretimin desteklenmesi

3) Küçük ölçekli firmaların, tasarıma, URGE'ye, inovasyona verilen teşviklerden faydalanabilmesinin mekanizmalarının oluşturulması.

4) Üniversite, sanayi işbirliğinin gerçek anlamda tesis edilmesi

5) Enerji fiyatlarının rakip ülkeler düzeyine çekilmesi

6) Büyük şehirlerdeki mevcut üretim tesislerinin şehir çeperlerinde kurulacak ihtisas organize sanayi bölgelerine taşınması ve bu bölgelerde üretim maliyetlerinin düşürülmesi, mekânsal yeniden yapılanma içine girecek işletmelere uygun finansman olanakları sağlanması, ilk 3 yıl kurumlar vergisi istisnası getirilmesi

7) Kümelenme düzenlemesi yapılarak mevcut kümelerde yatırımların desteklenmesi. Uzun yıllardır oluşan tedarik zincirleri ve kümelenmelerin bozulmaması, tüm küme unsurlarının desteklenerek mekânsal yeniden yapılanmanın gerçekleştirilmesi

8) Atı̆̆ı olmayan ve kirlilik yaratmayan giyim eşyaları imalatı gibi sanayi kolları için muafiyetler ve esneklikler tanınması

9) Sektörün içinde bulunduğu dönüşüm surecine uygun olarak orta vadede ihtiyaç duyduğu yeni nesil işgücü planlamasının yapılması,

10) Meslek liseleri, meslek yüksekokulları ve üniversiteler ile lisans ve doktora eğitim programlarının yenilenmesi, uygulama ağırlıklı eğitime geçilmesi, yeni nesil işgücü ihtiyacını karşılayacak eğitimler verilmesi,

11) Şirketlerin işbaşı eğitim programlarını arttırması, akredite kurumların verdiği eğitim harcamalarının desteklenmesi

12) Mesleki lise mezunlarının sektörde istihdamın özendirilmesi

13) Türkiye'de hazır giyim ve tekstil sektörü 'nün önemli temel hammaddesi olan iplik sanayi ve aksesuar ithalatında var olan anti-damping önlemlerinin gözden geçirilerek rekabet gücümüzü azaltmayacak hale getirilmesi

14) İlgili sektörlerle, bütünleşmiş iş modelleri oluşturması

\section{Pazarlama ve Satış}

\section{A. Sorunlar}

1) Aktif pazarlama ve tanitımın yeterince yapılmaması,

2) En büyük pazar $A B$ ekonomisindeki zayıflama,

3) Bölge ve çevre ülkelerindeki siyasi belirsizlikler ve istikrarsızlıklar sektörü olumsuz etkilemektedir. Alternatif ve potansiyel pazarlar için yeterli çalışma yapılması önem kazanmaktadır.

4) Hedef ülkelerden heyetlerin getirilmesinde; konaklama, ulaşım v.b. hizmetler konusunda yeterince devlet desteği alınamamaktadır.

5) Türk ticaret merkezlerinin açılması konusundaki gelişmeler yetersiz ve yavaştır.

\section{B. Çözüm Önerileri}

1) Yeni hedef pazarlara yönelik teşvik sistemi geliştirilmelidir.

2) Türk ticaret merkezlerinin realizasyonu hızlandırılmalıdır

3) Dünyada mağaza açma konusunda desteklerin arttırılması.

\section{Finansman}

\section{A. Sorunlar}

1) Türk lirasında dalgalanma sektörde öngörülebilirliği azaltmaktadır.

2) İşletme sermayesi yükü, önemli sıkıntılara yol açmaktadır.

3) Dövizdeki hareketlilik hazır giyim sektörünü olumsuz etkilemektedir 
4) Finansman maliyetleri ve koşulları işletmeler için önemli sorunların başında gelmektedir.

5) Proje finansmanı yoktur

6) Finansmanın; maliyetleri yüksektir ve ulaşılması çok güç şartlardadır

\section{B. Çözüm Önerileri}

1) Uygun koşullarda ve rakip ülkelerin koşullarında faizle kredi sağlanması

2) Kalkınma ve yatırım bankacılığının geliştirilmesi

\section{Piyasa ve Sektör Koşulları}

\section{A. Sorunlar}

1) Yüksek vergi uygulamaları ve yüksek üretim maliyetlerinin yol açtığı kayıt dışılık ve kayıt içi-kayıt dışı haksız rekabet ortamı,

2) Hazır giyim sektöründe firmalara üretim yapma fikri cazip gelmediğinden ötürü, sektörde kalma isteğinin zayıflaması ve sektöre yeni girişlerin sınırlı kalması

3) Yurtdışı piyasalarda daralma sektörü olumsuz etkilemektedir.

4) İç piyasada zincir mağaza ve AVM’lerin etkileri ağırlaşarak büyümektedir. İç piyasada müşteri daralması yaşanmaktadır.

5) Yerel firmalar AVM'lere sokulmamakta kısa sürede batmaktadırlar.

6) Yatırım teşvikleri kapsamında sektör için doğuya yatırım çekici değildir.

7) Kurumsallaşma ve markalaşma sorunu vardır.

\section{B. Çözüm Önerileri}

1) Kamu ile özel sektördeki tüm paydaşların katılımı ile uzun vadeli bir sektör strateji ve eylem planı hazırlanması ve uygulanması ile sektör için belirsizliklerin ortadan kaldırılması, ekonomi yönetimi ile uyumun sağlanması ve sektörün imajının iyileştirilmesi.

2) Öncelikle sektörün her türlü kapasite envanterinin çıkarılması ve bu envanterin güncellenmesi,

3) Kamu ve özel sektör nezdinde mevcut olan birçok sanayi, ihracat ve benzeri başlıklı sektör strateji belgelerinin uyumlaştırılması ve konsolidasyonu,

4) Hazır giyim ve konfeksiyon sektöründe önemi bir yurtdışı satış kapasitesi olan Osmanbey-Merter-Laleli bölgelerindeki faaliyetlerin özel bir statüye kavuşturularak mevcut sektör ve ekonomi ile kademeli şekilde entegrasyonu sağlanması ve fiziki sınırları belirlenecek ihracat odaklı serbest ticaret bölgeleri/alanları ilan edilmesi veya kurulmasi

\section{Mevzuat}

\section{A. Sorunlar}

1) AVM yasasının çıkması ve yerel firmalara yer verilmesi konusu yasada kesin olması gereken bir olgudur.

2) İhracat alanında ve teşviklerde yoğun, karmaşık ve ağır işleyen, ilave mali yükümlülükler getiren bir bürokrasi vardır

\section{B. Çözüm Önerileri}

1) Üretim maliyetleri yüksek olup, üretim maliyetlerindeki kamusal yüklerin makul ve rekabetçiliğimizi arttıracak düzeylere çekilmesi

2) Sektör içerisinde, özellikle tekstil sektöründe, KDV farklılıklarının giderilmesi

3) Türkiye' de üretilmeyen malların ithalatında veya ihracat amaçlı ithalatlarda KKDF alınmaması

4) Dâhilde İşleme Rejimi (DİR) uygulamalarında iyileştirmeler ile gümrük yönetmeliğinde değişiklik yapılması 8.İhracat

\section{A. Sorunlar}

1) Bölge ve çevre ülkelere yapılan özel satışların halen ihracat sayılmaması ve bu nedenle şirketlerin ihracat desteklerinden yararlanamaması

2) Aracı firma, uçak kargo gönderilen malların (bavul ticareti) ihracat sayılmaması.

3) Sektör ihracatında yaşanan düşüş 
4) Birçok ülkenin uyguladığı korumacı ve haksız rekabet yaratan politikalar var

\section{B. Çözüm Önerileri}

1) Yurtdışındaki ticaret müşavirlikleri kadrolarının artırılması

2) Eximbank tarafından sevk sonrası gerçekleşen ihracatlar ile ilgili izlenen prosedürün daha esnek hale getirilmesi (örneğin: İspanya ve İngiltere'ye yapılan ihracat kapsamında talep edilen teyit mektuplarının zorunluluğunun kaldırılması,

3) Yurt dışında markalı, toptan ve perakende satış faaliyetlerinde bulunan şirketlere yönelik destek programlarının geliştirilmesi,

4) Yurtdışı sektörel pazar bilgileri için bilgi bankası kurulması ve faaliyetlerinin desteklenmesi,

5) Özel fatura kapsamında gerçekleştirilen ihracatın, resmi ihracat rakamlarına dâhil edilebilmesi.

\section{9.İthalat}

\section{A. Sorunlar}

1) Üretim ağırlıklı bir anti damping sorununun olduğu, özellikle sektör için hammadde maliyetinin pahalı maliyetleri arttırması,

2) Polyesterde Uzakdoğu ile rekabet şansımız yoktur. Bu kapsamdaki korumacilık ancak sanayicinin o alanlarda üretimden çıkmasına yol açmaktadır.

3) Kimi ürünlerde yüzde 70’e varan gümrük vergisi kaçakçılığı teşvik etmektedir.

\section{B. Çözüm Önerileri}

1) Hammadde ve kumaşlar üzerindeki ek verginin kaldırılması ve üretemediğimiz malların girişinin serbest olmasi

2) Dâhilde İşleme Rejimi kapsamındaki ürünlerin gümrük giriş ve çıkış işlemleri esnasında kırmızı hat uygulamasının doğurduğu sıkıntılara çözüm bulunması ile kumaş karışım oranlarına ilişkin olarak gümrüklerce yapılan laboratuvar analizlerinin (ayniyat tespiti) kaldırılması veya artı ve eksilerinin tespit edilerek yaklaşık bir oranda tolerans tanınması. DİR kapatma işlemlerinde e-devlet belgelerinin resmi olarak kabul edilmesi

3) Dâhilde İşleme Rejimi kapsamında geçici kabullerde verilen 6 aylık sürenin üretim planlarına uygun olmaması nedeni ile 6 aylık sürenin uzatılması,

\section{0.Çalışma Mevzuatı}

\section{A. Sorunlar}

1) Kıdem tazminatıi sorunu işçi işveren çatışmasına dönmüştür, istihdamdaki sıkıntıları artırmıştır.

2) SGK tarafından yapılan işyeri denetimlerinin birbirinden habersiz birimlerce koordinesiz bir şekilde yapılması nedeniyle firmaların karşılaştıkları mağduriyetin giderilmesi amacıyla mükerrer denetimlerin önlenmesi ve üç ayda bir denetim yapılması

3) İş sağlığı ve güvenliğine ilişkin işyeri tehlike sınıfları" tebliği ilgili tebliğ kapsamında yapılan sınıflandırmaların sektör açısından hakkaniyetli olmadığı,

4) Sigorta primlerinin ve vergilerin yüksek oluşu

\section{B. Çözüm Önerileri}

1) Kıdem tazminatı fonu hukuki düzenlemesinin yapılması

2) Esnek ve yarı zamanlı çalışma olanaklarını getirilmesi, yerli ve yabancı nitelikli işgücünün esnek koşullarda istihdamına olanak sağlanması

\section{Teşvik Sistemi ve Yatırım}

\section{A. Sorunlar}

1) Geniş bir yelpazeye yayılan devlet destekleri alanında bilgi ve uygulama dağınıklığı nedeniyle işletmelerin yeterince yararlanamaması (bilgisi olmaması) ile aşırı bürokrasi nedeniyle yararlanma isteğinin sınırlanması.

2) Yurt dışında mağaza açanlara yapılan teşviklerin artırılması.

3) Bölgeler arasındaki farklı teşvik uygulamaları ile farklı üretim maliyeti yapılarının oluşması 
4) Beşinci ve altıncı bölgede sağlanan yatırım teşviklerinin dahi özellikle işgücü maliyetleri yönünden yetersiz kalması ve yatırımların yeterince teşvik edilememesi

5) Sanayideki yeni yatırımlar için desteklerin sadece 5. ve 6. bölge illeri ile sınırlanması ve bu illerde yetişmiş işgücü ve altyapının yetersiz olması

6) Teşvikin il bazında değil ilçe bazında da olması gerektiği, 4'üncü bölgedeki bir ilçenin 6'ncı bölgeden daha fakir olduğu durumların da olabildiği

7) Hazır giyimde kullanılan yatırım teşviklerinin sadece yüzde 20'sinin 6. Bölge'de kullanıldığ

8) Sanayi karlılı̆̆ı son yıllarda önemli ölçüde gerilemektedir. Sektör bu gelişmeden olumsuz etkilenmekte olup sektörden çıkışlar olmaktadır.

9) İlk yatırım sonrası yapılan ilave yatırımlarda orijinal teşvik unsurlarının uygulanması,

\section{B. Çözüm Önerileri}

1) Bölgede yatırım yapılacak ortam bugün itibariyle yoktur. 5. ve 6. Bölgeye sağlanan olanakların Batı'daki firmalara da verilmesi yatırımları arttıracaktır.

2) Mevcut tesislerdeki makinelerin yeni yatırımlar da teşvik uygulama kapsamına alınması

1.ve 2. bölgelerdeki modernizasyon yatırımlarının da bölgesel teşvik kapsamına alınması

3) Devlet yardımları kapsamında sağlanan tüm destekler ile özellikle Turquality ve marka destek programı kapsamındaki ödemelerin daha hızlı ve harcamalar ile birlikte yapılması, ödemelere ilişkin süreçlerin iyileştirilmesi yine bu kapsamda İhracatçı Birlikleri'ndeki ilgili uzman sayısının artırılması

4) Şirketlerde teşvik dosyalarını hazırlayan kişilerin yetkinliklerinin artıılması.

5) Sanayi üretiminde istihdamın sanayi dışı sektörlere göre pozitif ayrımcılık ile desteklenmesi

6) İlk yatırım sonrası yapılan ilave yatırımlarda orijinal teşvik unsurlarının uygulanması

7) Üretici firmaların çoğunluğunun şahıs firmaları olduğu ve devlet desteklerinin anonim ve limited şirketlere verildiği, bu sebeple şahıs firmalarının fuar desteklerinden ve ür-ge projelerinden faydalanamadıkları, imalat yapan herkesin desteklenmesinin gerektiği,

8) Giyim eşyası imalatı sanayi için desteklerde bölge kapsamının genişletilmesi

9) Devlet destekleri kapsamında alınan yardımların kurumlar vergisi matrahından muaf tutulması.

10) Tanıtım ve ticaret amaçlı moda partallarının kurulmasının ve yurtdışı tanıtımlarının yapılmasının desteklenmesi

11) Türk giyim eşyası markalarının bölge ülkelerinde tanıtımı ve bu amacla uygulanan yurtdışı tanıtım desteklerinin daha yaygın kullandırılması

12) İhracatı destek ve teşvik amaçlı olarak, makine yatırım teşvikine uygun ve uzun vadeli ödemelerle gerçekleştirilecek bir plan sağlanması

13) Yatırım teşviklerinde esneklikler sağlanması

14) KOSGEB desteklerini daha ulaşılabilir ve genişletilmesi. Örnek olarak katalog ve tanıtıcı reklam teşviki iki yılda bir ve çok düşük miktardadır.

15) Mevcut tesislerdeki makinelerin yeni yatırımlarda teşvik uygulama kapsamına alınması,

16) Birinci ve ikinci bölgelerdeki modernizasyon yatırımlarının da bölgesel teşvik kapsamına alınması

\section{Fuarlar}

\section{A. Sorunlar}

1) İstanbul'da büyük ölçekli iki fuar kurumunun rekabetinden ötürü kaynaklanan sorunlar vardır. Özellikle fuar tarihlerini çakışması ve talep görmeyen sektörlerle ilgili fuarların düzenlenmesi konularında sıkıntılar yaşanmaktadır.

2) Yurtdışı ülkelerde yapılan fuarlarda katma değerli ürünlerin sergilendiği, bu nedenle fuarlarda bulunan stantların kalitesine de dikkat edilmesi gerekmektedir. 


\section{B. Çözüm Önerileri}

1) Ülkemizde bulunan üretim potansiyelini yurtdışına taşımak yerine Avrupa'nın en büyük moda fuarını İstanbul'da gerçekleştirmek fikri üzerinde yoğunlaşılması

2) Sektörde milli fuarcıllı̆ı̆ı desteklenmesi

\section{Vergiler}

\section{A. Sorunlar}

1) Vergi maliyet yükleri, gerek finansmana erişim sorunları, üretimin gelişmesinin önünde ciddi bir engel oluşturuyor.

\section{B. Çözüm Önerileri}

1) Üretim ve istihdam üzerindeki vergi yüklerin azaltılması

14. Diğer Konular

\section{A. Sorunlar}

1) İstanbul'daki üretim tesislerinin yeni şehir planına göre mekânsal olarak yeniden yapılanma zorunluluğu vardir.

2) Resmi ve güncellenen bir sektör envanteri bulunmamaktadır.

3) Ulusal bir tekstil ve hazır giyim politikasını yoktur.

4) Şirketlerde kurumsallaşma yetersizdir.

5) Komşu ülkeler ile yaşanan güncel sorunlar;

Dış politikalarımız ve çevre ülkelerle yaşadığımız her gerginlik tüm ihracatımızı etkilediği gibi hazır giyim sektörünü de olumsuz etkilemektedir.

6) İhracatta lojistik destek yetersizdir.

7) Suriyelilerin açtığı kayıtdışı fason atölyeler haksız rekabet yaratmaktadır.

8) Avrupa Birliğinin 3. ülkelerle yaptığı anlaşmalardan sektör olumsuz etkilenmektedir. Transatlantik Ticaret ve Yatırım Anlaşması (TTIP) dışında kalmanın sektöre etkisi olumsuz olacaktır.

9) Asgari geçim indirimi ödemelerinin kamu desteği kapsamına alınmalıdır.

10) Dâhilde İşleme Rejiminin etkileri ve Dâhilde İşleme Rejimi kapsamında yurt dışından getirilen ürünlerin tamamının gümrüklerde kırmızı hat' ta düşmesi

11) Afrika'dan gelenlerin vize problemleri vardır

12) Sektörün imaj sorunu vardır.

\section{B. Çözüm Önerileri}

1) Rusya ile çalışan firmalara faizsiz bir kredi desteği sağlanması, Eximbank kredisi kullanan varsa, sürelerin uzatılması, özel banka kredilerinin kamu bankalarına aktarılması

2) Rusya'ya gönderdiği malı getirmek isteyen firmalara kolaylık sağlanması

3) Kur riskine karşı kullanılan araçlar üzerindeki ciddi yüklerin mutlak azaltılması

4) Sektörün ekonomideki liderlik vasıflarının on plana çıkarılması ve kamuoyunda tanıtımının yapılması,

5) Sektördeki donuşumun, yüksek katma değerli üretime geçişin, markalaşmanın, modern perakende pazardaki gelişmelerin aşamaları ve bunların yarattı̆̆ ilave katma değerin ekonomi yonetimi ve kamuoyu ile düzenli olarak paylaşılması.

6) İthalatta ve iç pazarda tüketici sağlığının korunmasına yönelik önlemler alınması

7) Serbest ticaret anlaşmaları, tercihli ticaret anlaşmaları gibi ekonomik entegrasyonlardan zarar görmememizi sağlayacak politikaların uygulanması 


\section{TÜRKIYYE HAZIR GIYYIM VE KONFEKSIYYON SEKTÖRÜNÜN ULUSLARARASI REKABET GÜCÜ}

Türkiye için Gümrük Tarifesi İstatistik Pozisyonunda; Fasıl 61 örme hazır giyim grubu, Fasıl 62 dokuma hazır giyim grubu ve Fasıl 63 diğer hazır giyim grubu bazında Türkiye hazır giyim ve konfeksiyon sektörünün uluslararası rekabet gücü Açıklanmış Karşılaştırmalı Üstünlükler (AKÜ) (Balassa,1965;Vollrath,1987;1989) yöntemi ile hesaplanmış ve sonuçları Tablo 10'da yer almaktadır.

Tablo 10. GTIP $(61$, 62, 63 ) için Hesaplanan AKÜ Değerleri, 2005-2018

\begin{tabular}{|l|l|l|l|l|l|l|l|l|l|l|l|l|l|l|}
\hline GTIP & $\mathbf{2 0 0 5}$ & $\mathbf{2 0 0 6}$ & $\mathbf{2 0 0 7}$ & $\mathbf{2 0 0 8}$ & $\mathbf{2 0 0 9}$ & $\mathbf{2 0 1 0}$ & $\mathbf{2 0 1 1}$ & $\mathbf{2 0 1 2}$ & $\mathbf{2 0 1 3}$ & $\mathbf{2 0 1 4}$ & $\mathbf{2 0 1 5}$ & $\mathbf{2 0 1 6}$ & $\mathbf{2 0 1 7}$ & $\mathbf{2 0 1 8}$ \\
\hline & & & & & & & & & & & & & & \\
61 & 372,4 & 340,8 & 316,1 & 275,6 & 254,1 & 252,6 & 262,5 & 274,06 & 279,1 & 275,0 & 255,6 & 264,10 & 274,55 & 278,75 \\
\hline 62 & 288,09 & 258,48 & 230,87 & 189,02 & 163,28 & 158,36 & 158,54 & 172,77 & 162,63 & 162,64 & 141,13 & 147,68 & 174,80 & 187,75 \\
\hline & & & & & & & & & & & & & & \\
63 & 372,47 & 343,07 & 311,93 & 295,99 & 285,07 & 284,80 & 271,48 & 267,64 & 290,36 & 268,17 & 248,55 & 246,88 & 264,66 & 264,66 \\
\hline
\end{tabular}

Kaynak: Kaynak: ITC Trademap verileri kullanılarak AKÜ hesaplamaları ile oluşturulmuştur

Grafik 3'de görüldüğü gibi; GTiP 61. Fasıl örme hazır giyim grubunda 2005 yılında 372,4 olan AKÜ değeri 2010 yılına kadar düşüş göstermiş ve 2010 yılında 252,65 değerine gerilemiştir. 2014 yılında AKÜ değeri 275,02 olmuş. 2018 yılında AKÜ değeri 278,78 değerine yükselmiştir. Örme hazır giyim grubunda 2005 yılına göre rekabet gücümüz gerilemiş olmakla birlikte 2008-2018 arası dönemde ortalama seviyesini muhafaza etmiştir.

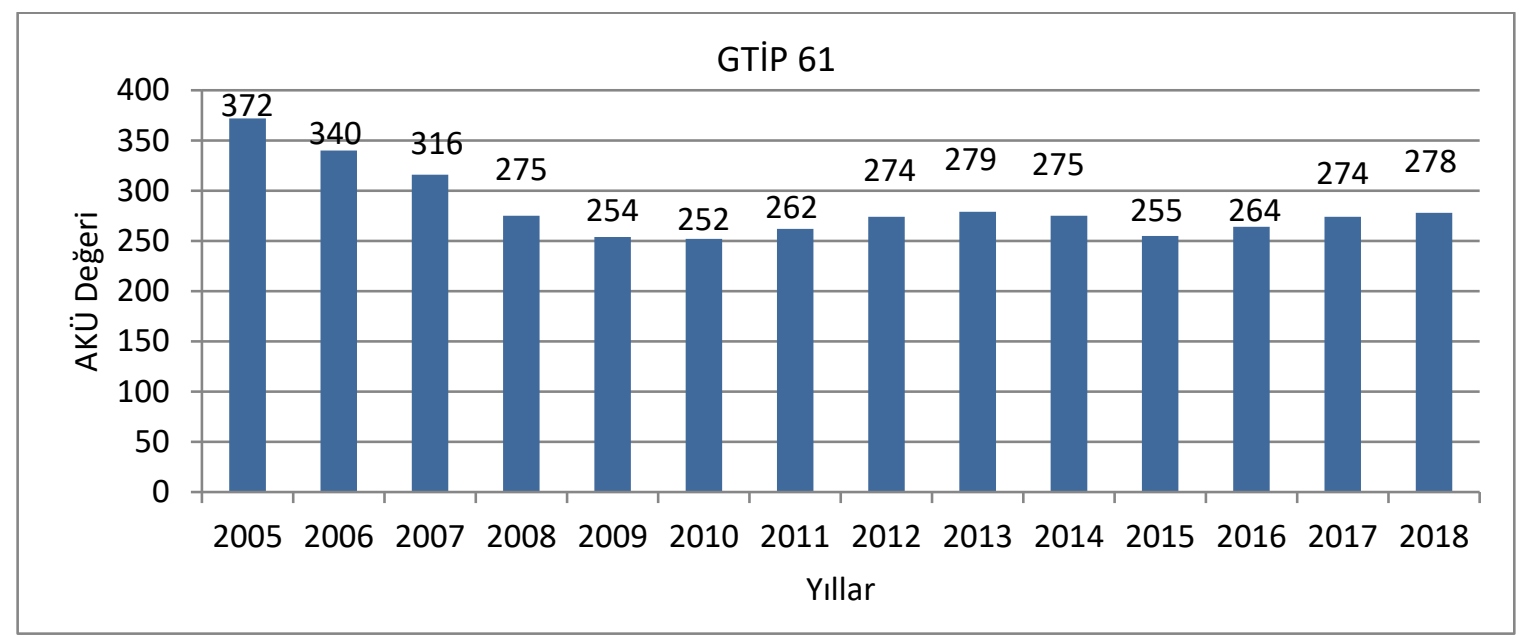

Grafik 3. GTİP 61. Fasıl Örme Grubu Ürünleri AKÜ Değerleri,2005-2018

Kaynak: AKÜ hesaplamalarından oluşturulmuştur

Grafik 3'de görüldüğü gibi; GTIP 62. Fasıl dokuma hazır giyim grubunda 2005 yılında 288,09 olan AKÜ değeri yıllar itibariyle düşüş trendi sergilemiş ve 2010 yılında 158,36 değerine kadar düşmüştür. Bu AKÜ değerleri; 2012 yılında 172,77; 2013 ve 2014 yıllarında sırasıyla 162,63 ve 162,64 olarak gerçekleşmiştir. 2015 ve 2016 yıllarındaki gerilemeden sonra 2017 ve 2018 yıllarında rekabet gücümüz artmış ve bu iki yılda AKÜ değerleri sırası ile 174,80 ve 187,75 olmuştur. 


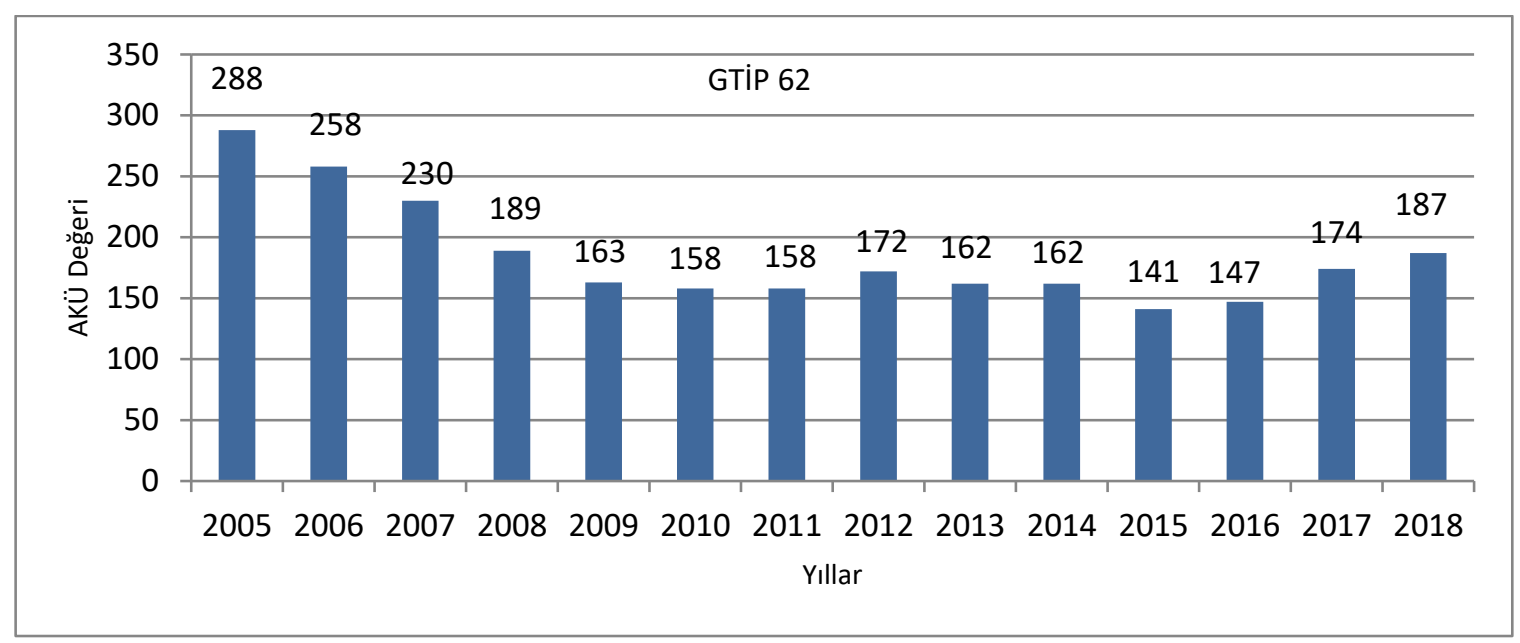

Grafik 4. GTiP 62. Fasıl Dokuma Grubu Ürünleri AKÜ Değerleri,2005-2018

Kaynak: AKÜ hesaplamalarından oluşturulmuştur

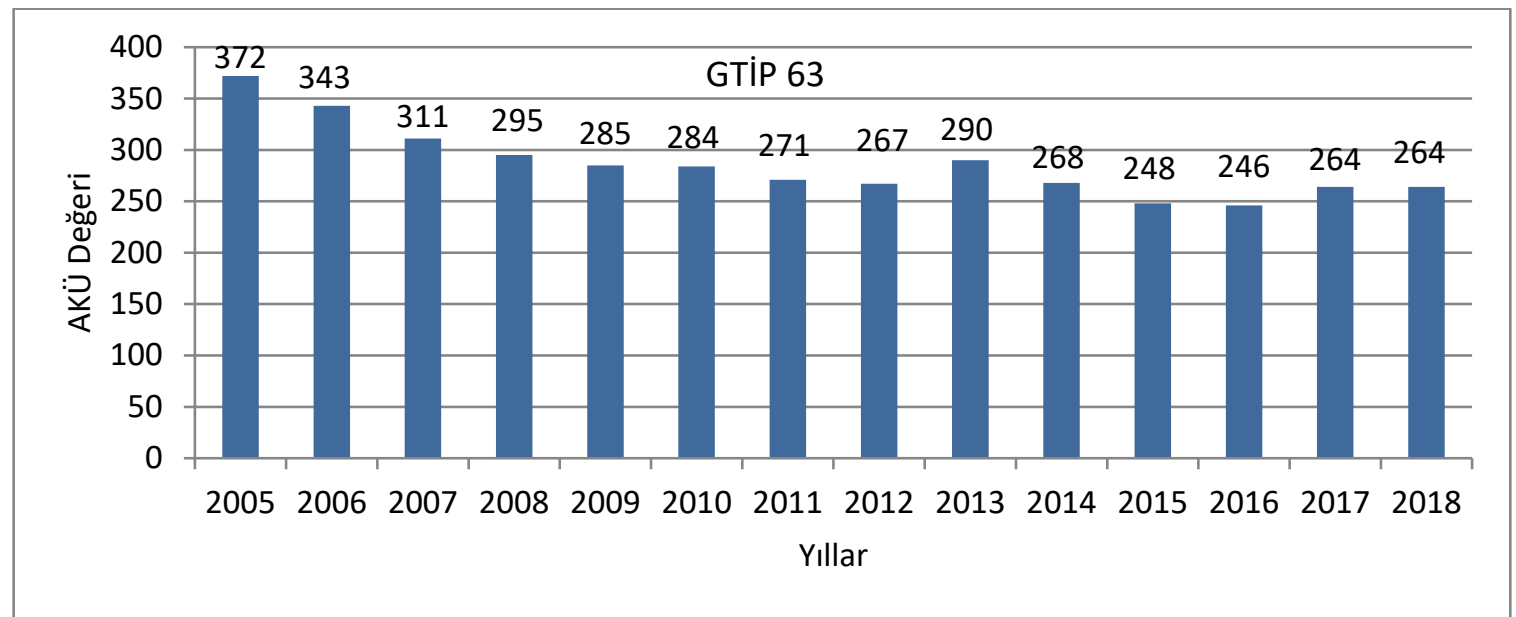

Grafik 5. GTiP 63. Fasıl Diğer Hazır Giyim Grubu Ürünleri AKÜ Değerleri,2005-2018Kaynak: AKÜ hesaplamalarından oluşturulmuştur

GTiP 63. Fasıl diğer hazır giyim grubunda 2005 yılında 372 olan AKÜ değeri yıllar itibariyle düşüş trendi sergilemiş ve 2010 yılında 284 değerine kadar düşmüştür. AKÜ değerleri 2012 yılında 267; 2013 ve 2014 yıllarında sırasıyla 290 ve 268 olarak gerçekleşmiştir. 2015 ve 2016 yıllarındaki gerilemeden sonra 2017 ve 2018 yıllarında rekabet gücümüz artmış ve bu iki yılda AKÜ değerleri 264 olmuştur.

\section{SONUÇ VE DEĞERLENDİRME}

Bu araştırma bağlamında Türkiye hazır giyim sektörünün öne çıkan sorunları olarak;

- Finansman yetersizliği ve finansman koşullarının uygun olmaması sektörün hayati problemlerinin başında gelmektedir.

- İthal girdi politikaları sektörün maliyet ve rekabet gücünü olumsuz etkilemektedir.

- İşü̈cü ve enerji maliyetlerinin rakip ülkelere göre yüksekliği rekabet gücümüzü azaltmaktadır.

- Ulusal tekstil ve hazır giyim politikasının oluşturulması büyük önem arz etmektedir.

- Teşvik ve yatırım mevzuatının sektöre rekabet gücü kazandıracak şekilde düzenlenmesine ihtiyaç duyulmaktadır. Teşvik, destekler ve uygulamalar konusunda sistem çok ağır işlemektedir.

- Başta “Kıdem Tazminatı” olmak üzere hukuki mevzuattan kaynaklanan kronikleşmiş sorunlar vardır.

- Çevre ülke pazarlarındaki sıkıntılar ve daralmalar nedeniyle yeni pazarlar oluşturulması konusunda devletin aktif desteğine ihtiyaç duyulmaktadır.

- Hammadde ve kumaşlar üzerindeki ek vergiler rekabet gücünü olumsuz etkilemektedir. 
- Üretim ve istihdam üzerindeki yükler yüksek olup maliyetlerin düşürülmesinde önem arz etmektedir.

Türkiye ekonomisinin lokomotif sektörlerinden olan hazır giyim sektöründe yaşanan bu ciddi olumsuzlukların bir krize dönüşmeden atlatabilmesi için;

- Devletin, üretim maliyetlerini düşürecek, uluslararası rekabet gücünü arttıracak vergi, SGK primleri, enerji maliyetleri ve benzeri alanlarda iyileştirmeler yapmasına,

- Sektörü küresel piyasalarda güçlendirecek yatırım, teknoloji, ar-ge ve üretim ile ilgili politika ve uygulamaların geliştirilmesi, destek ve teşviklerin getirilmesine,

- İhracat yapılan ülke pazarlarındaki sıkıntılar ve daralmalar nedeniyle yeni pazarlar oluşturulması konusunda devletin aktif desteğine, ihtiyaç duyulmaktadır.

Türkiye hazır giyim sektörü için, Gümrük Tarife İstatistik Pozisyonu 'nun 61'inci, 62'inci ve 63'üncü fasılları bağlamında 2005-2018 dönemindeki rekabet gücünün Açıklanmış Karşılaştırmalı Üstünlükler (AKÜ) yöntemi kullanılarak yapılan hesaplamalar ve analizler doğrultusunda; Türkiye hazır giyim sektörünün 2005-2018 yılları arasındaki dönem boyunca yüksek rekabet gücünün olduğu görülmektedir. Sektörün uluslararası rekabet gücü; 2005 ile 2009 yılları arasında gerilemiş, 2010-2018 yılları arasında yaklaşık aynı kalmıştır. Türkiye'nin rekabet gücünün 2005 yılından sonra sergilediği gerileme trendi, Çin'in Dünya Ticaret Örgütü'ne katılımı ve diğer gelişmekte olan ülkelerin emek yoğun bu sektördeki pazara giderek daha yoğun şekilde katılmaları nedeniyle artan küresel rekabetten olumsuz etkilendiğini göstermektedir.

Dünya ekonomisinde yaşanan küreselleşme ve yeni ekonomi/bilgi ekonomisi sürecinin sektörün tasarımdan pazarlamaya, hammaddelerden pazar yapısına, değer zincirinin hemen her aşamasında büyük değişimler meydana getirmekte olduğu değerlendirilmektedir. Sektördeki "hiper rekabet"te ülkelerin rekabet güçlerini sürdürebilmeleri bu değişime ayak uydurabilmelerine bağlıdır. Bu noktada değişimin makro ve mikro dinamiklerinin irdelenerek devletin ve sektörün birlikte gerekli politika ve uygulamaları üretmesi bir zorunluluk arz etmektedir. Sektörün devlet olmadan mikro faktörleri etkilemesi ve yönetmesiyle sektördeki değişime ayak uydurulabilmesi mümkün değildir. Bu bağlamda sektör rekabet gücü stratejisinin devlet, sektör ve üniversite işbirliği ile ortaya konularak uygulamaya geçirilmesi önem taşımaktadır.

\section{KAYNAKÇA}

Adıgüzel, M. (2011 a). Uluslararası Rekabet Gücü: Belirleyici Faktörler ve Ölçülmesi, Nobel Yayın.

Adıgüzel, M. (2011 b).Türkiye ekonomisi ve stratejik dönüşümü, Nobel Akademik Yayıncllık.

Allwood, J.M., Laursen, S.E., Rodrigues, C.M., Bocken, N.M.P.(2015). Well dressed? The Present and Future Sustainability of Apparel and Textiles in the United Kingdom, Journal of the Home Economics Institute of Australia, Volume: 22, Issue 1 (2015), pp. 42

Armstrong, C.M., Niinimäki, K., Lang, C. and Kujala, S. (2016), “A Use-Oriented Clothing Economy? Preliminary Affirmation for Sustainable Clothing Consumption Alternatives", Sustainable Development, Vol. 24 No. 1, pp. 18-31.

Aydoğdu, Gül.(2012). “ Hazır Giyim ve Konfeksiyon Raporu”, Çukurova Kalkınma Ajansı Raporu, s.1-34.

Balassa, B. (1965). "Trade Liberalization and Revealed Comparative Advantage”, The Manchester School of Economic and Social Studies, Vol:33, No:2.

Bayrampaşa Tekstilci ve Sanayici İş Adamları Derneği (2015): “Hazır Giyim Sektörü Sorunlar ve Çözüm Önerileri" Yayınlanmamış Rapor;

Dilek Şahin(2015). Türkiye ve Çin'in Tekstil Ve Hazır Giyim Sektöründe Rekabet Gücünün Analizi, Akademik Bakış Dergisi Sayı: 47 Ocak - Şubat 2015, S.155-171

Elçin Aykaç Alp, Mete Han Yağmur (2017): İstanbul Ticaret Odası Ticari Faaliyet Endeksi ve Meslek Komiteleri Tespit ve Önerileri, İstanbul Ticaret Odası - İstanbul Ticaret Üniversitesi, İstanbul 
Fernandez-Stark ,K. , Frederick, S. and Gereffi, G. (2011). The Apparel Global Value Chain: Economic Upgrading and Workforce Development Center on Globalization, Governance \& Competitiveness, Duke University,

Gereffi, G. and Memedovic, O. (2003) The Global Apparel Value Chain: What Prospects for Upgrading by Developing Countries? United Nations Industrial Development Organization, Vienna.

Gereffi, G. ve Frederick,S.(2010). The Global Apparel Value Chain, Trade and the Crisis: Challenges and Opportunities for Developing Countries, The World Bank,WPS5281

Hiller Connell, K.Y. (2010), “Internal and external barriers to eco-conscious apparel acquisition”, International Journal of Consumer Studies, Vol. 34 No. 3, pp. 279-86.

Gill, A., Lopes, A.M. and Kaye-Smith, H. (2016), “Practicing Sustainability. Illuminating 'use' in wearing clothes", Cultural Studies Review, Vol. 22 No. 1, pp. 32-58

http://www.sgk.gov.tr/wps/portal/sgk/tr/kurumsal/istatistik/sgk_istatistik_yilliklari, (Erişim tarihi: 15.8.2019)

ITC Trademap,www.trademap.org, (Erişim tarihi: 10.5.2019-21.8.2019 arası)

İHKIBB (2014). İstanbul Hazır Giyim ve Konfeksiyon İhracatçıları Birliği 2014 Yılı Faaliyet Raporu, İstanbul

İstanbul Ticaret Odası (2015): 16 Aralık 2015 tarihli Hazır Giyim ve Konfeksiyon Sektörü Sorunları Çalışma Toplantısı Tutanakları

Laleli Sanayici ve İşadamları Derneği(2015): “Rusya Federasyonu İle Yaşadığımız Ticari Sorunlara İlişkin Çözüm Önerileri" Yayınlanmamış Rapor;

Merter Sanayici ve İşadamları Derneği (2015): “Hazır Giyim Sektörü Sorunları” Yayınlanmamış Rapor, İstanbul

MÜSİAD (2014);Tekstil ve Hazır Giyim Sektörünün Dönüşüm Stratejileri ve Yeni Yol Haritası, İstanbul

Niinimäki, K. and Hassi, L. (2011), "Emerging design strategies in sustainable production and consumption of textiles and clothing", Journal of Cleaner Production, Vol. 19 No. 16, pp. 1876-1883

Osmanbey Tekstilci İş Adamları Derneği (2015); “Hazır Giyim Sektörünün Sorunları ve Çözüm Önerileri” Yayınlanmamış Rapor

Özçalık, M. ve Okur A. 2013, ‘Türk Tekstil ve Hazır Giyim Sektörlerinin Gümrük Birliği Sonrası AB-15 Ülkeleri Karşısındaki Rekabet Gücü", CBÜ Sosyal Bilimler Dergisi, Yıl: 2013, Cilt: 11 Sayı: 1, S.201-223

Özkaya, H. (2010). “Tekstil Sektöründe Endüstri İçi Ticareti Etkileyen Faktörler Üzerine Ampirik Çalışma.” Uşak Üniversitesi Sosyal Bilimler Dergisi, 3(2), 136-157.

Sosyal Güvenlik Kurumu İstatistikleri,

T.C. Bilim, Sanayi ve Teknoloji Bakanlığı (2014); Tekstil, Hazır Giyim ve Deri Ürünleri Sektörleri Raporu (2014/1), Sanayi Genel Müdürlüğü, Ankara

T.C. Kalkınma Bakanlığı (2014): Onuncu Kalkınma Planı (2014-2018),Tekstil - Deri - Hazır Giyim Çalışma Grubu Raporu

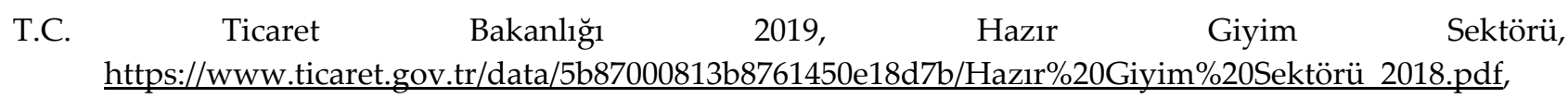

Erişim tarihi: 9.8.2019,

Tekstil ve Hazır Giyim Sanayiinin Türk Ekonomisindeki Yeri, İstanbul

TGSD,(2016).Türk Hazır Giyim Sektörü İçin Yol Haritası, Türkiye Giyim Sanayicileri Derneği,

TKB (2016). Belirli Göstergelerle İmalat Sanayiindeki Aylık Gelişmeler (2016). Türkiye Kalkınma Bankası A.Ş., Ankara

TÜIKK, Türkiye İstatistik Kurumu Veri Tabanı

TÜSİAD (2014). İmalat Sanayi Rekabet Göstergeleri Raporu, TÜSİAD, İstanbul 
M. Adigüzel 11/4 (2019) 3485-3504

VOLLRATH, Thomas L. (1987): Revealed Competitiveness for Wheat, Economic Research Service Staff Report No. AGES861030, Washington.

(1989): Competitiveness and Protection in World Agriculture, Agricultural Information Bulletin No.567, Washington.

YÜCEL, Y. (2010). “Uluslararası Ticaretin Serbestleştirilmesi Sürecinde Türk Tekstil ve Hazır Giyim Sektörünün Rekabet Gücü ve Çin Tehdidi", Marmara Üniversitesi İktisadi ve İdari Bilimler Fakültesi Dergisi, Y: 2010, C: 29, S: 2., s. 227-250. 